\title{
Plant regeneration and transformation of Trachyspermum ammi using Agrobacterium tumefaciens and zygotic embryos
}

Masoumeh Nomani ${ }^{1}$ and Masoud Tohidfar ${ }^{2^{*}}$

\begin{abstract}
Background: Trachyspermum ammi is one of the key medicinal plant species with many beneficial properties. Thymol is the most important substance in the essential oil of this plant. Thymol is a natural monoterpene phenol with high anti-microbial, anti-bacterial, and anti-oxidant properties. Thymol in the latest research has a significant impact on slowing the progression of cancer cells in human. In this research, embryos were employed as convenient explants for the fast and effectual regeneration and transformation of T. ammi. To regenerate this plant, Murashige and Skoog (MS) and Gamborg's B5 (B5) media were supplemented with diverse concentrations of plant growth regulators, such as 6-benzyladenine (BA), 1-naphthaleneacetic acid (NAA), 2,4-dichlorophenoxyacetic acid (2, 4-D), and kinetin (kin). Transgenic Trachyspermum ammi plants were also obtained using Agrobacterium-mediated transformation and zygotic embryos explants. Moreover, two Agrobacterium tumefaciens strains (EHA101 and LBA4404) harboring pBl121-TPS2 were utilized for genetic transformation to Trachyspermum ammi.
\end{abstract}

Results: According to the obtained results, the highest plant-regeneration frequency was obtained with B5 medium supplemented with $0.5 \mathrm{mg} / \mathrm{l} \mathrm{BA}$ and $1 \mathrm{mg} / \mathrm{I} \mathrm{NAA}$. The integrated gene was also approved using the PCR reaction and the Southern blot method. Results also showed that the EHA101 strain outperformed another strain in inoculation time (30 s) and co-cultivation period (1 day) (transformation efficiency 19.29\%). Furthermore, HPLC method demonstrated that the transformed plants contained a higher thymol level than non-transformed plants.

Conclusions: In this research, a fast protocol was introduced for the regeneration and transformation of Trachyspermum ammi, using zygotic embryo explants in 25-35 days. Our findings confirmed the increase in the thymol in the aerial part of Trachyspermum ammi. We further presented an efficacious technique for enhancing thymol content in Trachyspermum ammi using Agrobacterium-mediated plant transformation system that can be beneficial in genetic transformation and other plant biotechnology techniques.

Keywords: Plant growth regulators, HPLC, Zygotic embryo, Transgenic, PCR, Southern blot

\footnotetext{
* Correspondence: m_tohidfar@sbu.ac.ir

${ }^{2}$ Department of Plant Biotechnology - College of Life Science and

Biotechnology, Shahid Beheshti University, Daneshjou Boulevard, Tehran

19839-63113, Iran

Full list of author information is available at the end of the article
}

\section{Springer Open}

(c) The Author(s). 2021 Open Access This article is licensed under a Creative Commons Attribution 4.0 International License, which permits use, sharing, adaptation, distribution and reproduction in any medium or format, as long as you give appropriate credit to the original author(s) and the source, provide a link to the Creative Commons licence, and indicate if changes were made. The images or other third party material in this article are included in the article's Creative Commons licence, unless indicated otherwise in a credit line to the material. If material is not included in the article's Creative Commons licence and your intended use is not permitted by statutory regulation or exceeds the permitted use, you will need to obtain permission directly from the copyright holder. To view a copy of this licence, visit http://creativecommons.org/licenses/by/4.0/. 


\section{Background}

Medicinal plants are the most preferred topic for the plant biotechnology researcher, because of their pharmaceutical combination. In many parts of the world, utilization of medicinal plants is of highly important because of health care [1]. Trachyspermum ammi is a traditional and medicinal herb, which is highly effective in curing various human and animal diseases. This plant is also of nutritional and medicinal importance.

Achievements in in vitro regeneration and reproduction of medicinal plants rely on many elements [2]. For example, the shortest and most efficient protocol for explant propagation is of great value in tissue culture and gene transfer methods. Several studies have been conducted on the regeneration of T. ammi with different explants, all of which took a long time to regenerate [3-7]. However, as far as we know, there is no survey about tissue culture by means of zygotic embryo explants for this plant. The success of the embryo propagation technique depends on isolating the embryo and determining the appropriate culture media and growth regulators. Auxin and cytokinin growth regulators have a significant role in growth quality in embryos. In the former research works, the efficacy of auxins and cytokinins in regeneration of several medicinal plants has been studied [8-10]. Biotechnology by techniques, such as cell and tissue culture, genetic engineering, molecular markers, metabolic engineering, and gene overexpression have proven to be able to enhance the effectiveness of medicinal plants as a renewable resource for drug production $[11,12]$.

Terpenoids are one of the most diverse classes of natural products. Based on Agrobacterium-mediated genetic evolution, several plant metabolic engineering strategies are promising to regulate the biosynthesis of medicinal terpenoids such as overexpression of terpenoid biosynthesis pathway genes in plants and suppression expression of competitive metabolic pathways [13]. During the recent years, using overexpression, several monoterpene and sesquiterpene synthases have been changed to generate new monoterpenes, and sesquiterpenes that were present in floral and green tissues [14, 15]. Moreover, much attention has been lately paid to the synthesis pathways of terpenes. Most terpenes in herbs are involved in producing secondary metabolites [16]. TPS2 is one of the most important synthesizing enzymes of monoterpenes [17]. Previous studies on T. vulgaris have demonstrated that $\gamma$-terpinene is a major precursor in the aromatic monoterpene pathway leading to production of p-cymene, thymol, and carvacrol by the terpene synthase $2[17,18]$. However, nowadays, production of the most secondary metabolites is possible through manipulation of synthesis pathways in medicinal plants [19, 20]. Thymol is a valuable and the main essential oil existing in T. ammi [21]. Many of the therapeutic properties of this plant are relevant to thymol [22]. In brief, transgenic plants' procedure consists of transferring the selected gene into an extremely totipotent explant using Agrobacterium strains and development of regenerated plants [23]. On the other hand, optimization of gene transfer process plays an important role in the success of plant transformation. The transformation of the GUS gene along with Agrobacterium has been carried out in some medicinal plants [24-26].

Previous studies reported that overexpression of $T Y D C 2$ in the opium poppy led to an increase in morphine, codeine, and the baine alkaloids in the transgenic plants compared to the non-transgenic plants [27]. The findings of previous research on overexpression of codeinone reductase in Papaver bracteatum revealed the production of Codeine ( $0.04 \%$ dry wt) and morphine $(0.28 \%$ dry wt) in the transgenic hairy root [28]. It was demonstrated that overexpression of SmMYC2 in Salvia miltiorrhiza resulted in the production of phenolic acids [29]. Jiang carried out overexpression of AaWRKY1 in Artemisia annua and showed that AaWRKY1 increased the content of artemisinin in this plant [30]. In another major study on Artemisia annua, it was found that overexpression of the cytochrome P450 monooxygenase and cytochrome $\mathrm{P} 450$ reductase genes can increase artemisinin level [31]. In this report, we described the application of an Agrobacterium-mediated transformation system to a T. ammi (Shaheideh Yazd). This method combines the use of the zygotic embryo as an explant and the ability of Agrobacterium for transformation cells. Zygotic embryo explant is superior to other regeneration systems due to its independent genotype. The zygotic embryo has been accepted as an adequate explant for tissue culture and genetic transformation in many medicinal plants [32-35]. Since, there have been difficulties with the regeneration of plants from Agrobacterium-infected zygotic embryo, the Trachyspermum ammi transformation system is established. Therefore, this research aimed to provide a fast procedure to increase thymol using zygotic embryos explant for overexpressing TPS gene in T. ammi. This presented procedure can be beneficial for the genetic transformation of other genes and further biotechnology studies.

\section{Methods}

Seed disinfection, preparation of explants, callus induction, and regeneration

The mature seeds of $T$. ammi (ecotype of Shaheideh Yazd) were provided from the Research Institute of Forests and Rangelands of Iran. For seed disinfection, they were first submerged in $70 \%$ ethyl alcohol and Tween-20 for $60 \mathrm{~s}$. Next, they were disinfected with $1.5 \%$ sodium hypochlorite $(\mathrm{SH})(\mathrm{w} / \mathrm{v})$ for $3 \mathrm{~min}$ by gentle agitation. Then, sterilized seeds were rinsed at least three 
times with sterile double-distilled water (each for time lasting $5 \mathrm{~min}$ ). Afterwards, the seeds were dried on a sterile paper and were located in $50 \mathrm{ml}$ conical tubes containing autoclaved water for $24 \mathrm{~h}$ in a growth chamber at $25 \pm 2^{\circ} \mathrm{C}$ under $16 / 8 \mathrm{~h}$ (light/darkness) photoperiod. After $24 \mathrm{~h}$, the seeds were placed on a filter paper for $3 \mathrm{~min}$ in a sterile situation. Afterwards, embryos were separated from swollen seeds and used as explants. Isolated embryos were cultured on MS [36] and B5 [37] media supplemented with different concentrations of NAA, BA, 2,4-D, KIN, 3\% $(\mathrm{w} / \mathrm{v})$ sucrose, and $0.7 \%(\mathrm{w} / \mathrm{v})$ agar. Before autoclaving $\left(121^{\circ} \mathrm{C}, 1.04 \mathrm{~kg} \mathrm{~cm}^{2}, 20 \mathrm{~min}\right)$ of media, $\mathrm{pH}$ was adjusted to 5.7-5.8. The Petri dishes were incubated in the growth chamber at $25 \pm 2^{\circ} \mathrm{C}$ with the light intensity of about 2000 Lux provided by white fluorescent lamps and photoperiod of $16 / 8$ h. Furthermore, to assess the effect of growth regulators on zygotic embryo propagation, different of various concentrations of NAA $(0.5,1,2)$, BA $(0,0.5,1), 2,4-\mathrm{D}(0.5,1,2)$, and $\operatorname{KIN}(0.2,0.5,1)$ on B5 (salts + vitamins) or MS (salts + vitamins) media were applied (Table 1 ).

After culturing the embryos, calluses were appeared after $8-10$ days. The callus induction was determined as following formula:

$$
\text { Callus induction }=\frac{\text { Number of calluses }}{\text { Total number of zygotic embryos }} \times 100
$$

Afterwards, callus was transmitted to a fresh medium with the same growth regulators for regeneration, and after 12 days, the percentages of plantlets were counted as following formula:

$$
\text { Regenertion }=\frac{\text { Number of plantlet }}{\text { Total number of calluses }} \times 100
$$

Following the determination of calluses fresh weight, we dried them in an oven at $60^{\circ} \mathrm{C}$ for $24 \mathrm{~h}$ and their dry weights were measured. Additionally, after regeneration, the roots of the plantlets were rinsed with tap water. Subsequently, to maintain humidity, the plantlets were placed in plastic pots containing a mixture of sterilized soil vermiculite, garden soil, and perlite with plastic covers for 10 days. Eventually, the plantlets were cultured in larger pots and placed in the greenhouse.

\section{Bacterial strain and plasmid}

The transgenic T. ammi was prepared using hypocotyl explants [38], but this method produces a small number of plants and is time-consuming. So, another procedure was used to produce more transgenic plants in a shortest

Table 1 Effect of Murashige and Skoog (MS) and Gamborg's B5 (B5) media with diverse concentrations of plant growth regulators, 6-benzyladenine (BA), 1-naphthaleneacetic acid (NAA), 2,4-dichlorophenoxyacetic acid (2,4-D), and kinetin (KIN) to regenerate

\begin{tabular}{|c|c|c|c|c|c|c|c|c|c|c|}
\hline BA & $\begin{array}{l}\text { Treatment } \\
\text { NAA }\end{array}$ & $\begin{array}{l}(\mathrm{mg} / \mathrm{l}) \\
2,4-\mathrm{D}\end{array}$ & KIN & Medium & $\begin{array}{l}\text { Callus } \\
\text { induction } \\
(\%)\end{array}$ & $\begin{array}{l}\text { Fresh Weight } \\
\text { of callus } \\
\text { (mg) }\end{array}$ & $\begin{array}{l}\text { Dry Weight } \\
\text { of callus } \\
\text { (mg) }\end{array}$ & $\begin{array}{l}\text { Height of shoot } \\
\text { (cm) }\end{array}$ & $\begin{array}{l}\text { Regeneration } \\
(\%)\end{array}$ & $\begin{array}{l}\text { Average number } \\
\text { of shoots }\end{array}$ \\
\hline 0 & 0.5 & 0 & 0 & B5 & $68^{c}$ & 0.47 & $0 / 03$ & 7.65 & $62.7^{c}$ & $4.7^{b}$ \\
\hline 0 & 1 & 0 & 0 & B5 & $56^{d}$ & 0.41 & 0.034 & 7.21 & $65.5^{c}$ & $4.01^{b c}$ \\
\hline 0 & 2 & 0 & 0 & B5 & $52^{d}$ & 0.44 & 0.032 & 6.97 & $77.4^{b c}$ & $4.12^{\mathrm{bc}}$ \\
\hline 0.5 & 0.5 & 0 & 0 & B5 & $84^{\mathrm{b}}$ & 0.48 & 0.031 & 9.54 & $83.4^{\mathrm{b}}$ & $4.23^{b c}$ \\
\hline 0.5 & 1 & 0 & 0 & B5 & $98^{\mathrm{a}}$ & 0.53 & 0.034 & 10.23 & $92.6^{a}$ & $5.9^{\mathrm{a}}$ \\
\hline 0.5 & 2 & 0 & 0 & B5 & $80^{\mathrm{bc}}$ & 0.41 & 0.029 & 9.12 & $89.97^{b}$ & $4.8^{\mathrm{b}}$ \\
\hline 1 & 0.5 & 0 & 0 & B5 & $88^{b}$ & 0.43 & 0.031 & 9.93 & $76.6^{b c}$ & $4.9^{\mathrm{b}}$ \\
\hline 1 & 1 & 0 & 0 & B5 & $74^{\mathrm{bc}}$ & 0.37 & 0.027 & 9.17 & $80.75^{b c}$ & $4.54^{b c}$ \\
\hline 1 & 2 & 0 & 0 & B5 & $44^{e}$ & 0.29 & 0.018 & 9.19 & $68.5^{c}$ & $3.7^{c}$ \\
\hline 0 & 0 & 0.5 & 0.2 & MS & $72^{\mathrm{bc}}$ & 0.31 & 0.028 & 7.76 & $58.8^{d}$ & $3.87^{c}$ \\
\hline 0 & 0 & 0.5 & 0.5 & MS & $64^{c}$ & 0.37 & 0.021 & 7.98 & $56.2^{d}$ & $3.54^{c}$ \\
\hline 0 & 0 & 0.5 & 1 & MS & $56^{d}$ & 0.39 & 0.023 & 6.74 & $49 d^{e}$ & $2.5^{\mathrm{cd}}$ \\
\hline 0 & 0 & 1 & 0.2 & MS & $96^{\mathrm{a}}$ & 0.41 & 0.029 & 9.97 & $82.5^{b}$ & $3.9^{c}$ \\
\hline 0 & 0 & 1 & 0.5 & MS & $88^{b}$ & 0.47 & 0.032 & 7.54 & $79.9^{b c}$ & $3.76^{c}$ \\
\hline 0 & 0 & 1 & 1 & MS & $78^{\mathrm{bc}}$ & 0.31 & 0.029 & 6.98 & $68.2^{c}$ & $1.97^{d}$ \\
\hline 0 & 0 & 2 & 0.2 & MS & $52^{d}$ & 0.38 & 0.021 & 7.12 & $61.7^{d}$ & $3.81^{c}$ \\
\hline 0 & 0 & 2 & 0.5 & MS & $44^{e}$ & 0.33 & 0.027 & 6.34 & $51.3^{\mathrm{de}}$ & $2.87^{c d}$ \\
\hline 0 & 0 & 2 & 1 & MS & $31^{f}$ & 0.27 & 0.018 & 5.53 & $41.1^{\mathrm{e}}$ & $1.89^{d}$ \\
\hline
\end{tabular}
Trachyspermum ammi by zygotic embryos

${ }^{a-f}$ Means with different superscripts within the same column differ significantly $(P \leq 0.05)$ using Duncan 
period of time. We also used Agrobacterium tumefaciens EHA101 and LBA4404 with the genetic construct of pBI121-TPS2 as well as zygotic embryos. This vector contains the TPS and neomycin phosphotransferase (nptII) gene, as a selectable marker. To optimize transformation factors, a strain of Agrobacterium harboring the binary vector pBI121 possessing the GUS gene was also used.

\section{Transformation, co-cultivation, and regeneration of transgenic plants}

To determine the appropriate level of kanamycin for gene transfer, zygotic embryos were isolated (as explained in the previous section) and placed on the media (best chosen media based on tissue culture) with diverse levels of kanamycin $(0,5,10,15,20,25,30,50$, and 75 $\mathrm{mg} / \mathrm{l})$. Kanamycin was added following the preparation of autoclaved selective medium and after cooling (40$50^{\circ} \mathrm{C}$ ) in a laminar flow hood. In the transformation step, a single Agrobacterium colony grown on LB solid medium with kanamycin $(50 \mathrm{mg} / \mathrm{l})$ was cultured for $48 \mathrm{~h}$ and then transferred to the conical tube containing LB liquid with suitable antibiotics and incubated overnight in an incubator at $28^{\circ} \mathrm{C}$ on a rotary shaker $(\mathrm{OD} 600=$ 0.4-0.6). Additionally, in transformation processing, two vectors, pBI121-TPS and pBI121, were used. In the laminar hood, the embryos were separated from seeds (described previous) and immersed in bacterial suspension in $15-\mathrm{ml}$ conical tubes several times $(30 \mathrm{~s}, 1 \mathrm{~min}, 2 \mathrm{~min}$, $3 \mathrm{~min}$, and $5 \mathrm{~min}$ ) with gentle shaking. Then, they were put on sterile paper to get dried after inoculation. In the next step, the explants were placed on co-cultivation medium (best chosen media with antibiotics) at diverse times ( 1 and 2 days). Finally, they were cultured on callus induction medium adding $15 \mathrm{mg} / \mathrm{l}$ kanamycin and $180 \mathrm{mg} / \mathrm{l}$ cefotaxime to inhibit Agrobacterium strains' growth and were placed in a growth chamber.

\section{Molecular analysis, histochemical GUS assay, and RT-PCR} In the present research, total genomic DNA of the plant was extracted from leaves of the transformed and nontransformed herbs to be used for PCR and subsequently verify the presence of genes in transgenic herbs (Table 2). The PCR status was identified as follows: initial denaturation for $5 \mathrm{~min}$ at $94^{\circ} \mathrm{C}$, then 35 subsequent cycles of denaturation runs for $1 \mathrm{~min}$ at $94^{\circ} \mathrm{C}$, annealing at $60^{\circ} \mathrm{C}$ (GUS), $61^{\circ} \mathrm{C}$ (TPS2), and $62^{\circ} \mathrm{C}$ (nptII) genes for $1 \mathrm{~min}$ then extension at $72^{\circ} \mathrm{C}$ for $45 \mathrm{~s}$ and the last extension at $72^{\circ} \mathrm{C}$ for $5 \mathrm{~min}$. GUS expression was also determined for randomly selected transformed plants. The histochemical GUS test was performed based on Jefferson instruction [39]. Small samples were isolated from leaves of the transformed and non-transformed plants and immersed in 1.5-ml tubes. Then, X-gluc (5-bromo-4-chloro-3-
Table 2 Nucleotide sequences of primers used in PCR

\begin{tabular}{ll}
\hline Gene & $\begin{array}{l}\text { Primer sequences } \\
\text { 5' to 3' }\end{array}$ \\
\hline Gus & F: 5' ACCTCGCATTACCCTTACGCTGAA 3' \\
& R: 5' AATCGCCGCTTGGACATACC 3' \\
Tps2 & F: 5' ACTCGTCTCCGTCCTATC 3' \\
& R: 5' CGTCCTTCGTATTCTCAC 3' \\
nptll & F: 5' GTCATCTCACCTTGCTCCTGC 3' \\
& R: 5' AAGAAGGCGATAGAAGGCG 3' \\
Vir G & F: 5' ATGATTGTACATCCTTCACG 3' \\
& R: 5' TGCTGTTITATCAGTTGAG 3' \\
\hline
\end{tabular}

indolyl- $\beta$-glucuronidase) buffer was added into the tubes and kept at a temperature of $37^{\circ} \mathrm{C}$ (room temperature) for $24 \mathrm{~h}$. Afterward, the solution was taken out of the tube and the plants immersed in $70 \%$ ethanol for $4 \mathrm{~h}$. Finally, the samples were observed under a binocular stereomicroscope.

The total RNA from leaves of transformed plants was extracted using trizol (Invitrogen, USA) for final verification of the transformed plants and stable expression of GUS gene. After treatment with DNase, the first cDNA strand was produced by a cDNA synthesis kit (Eurex) and Oligo-dT primer. Finally, two strands of cDNA were synthesized in a thermal cycler (Bio-Rad) by specific primers.

\section{DNA gel-blot analysis and HPLC}

Ten micrograms of DNA were digested with an EcoRI enzyme that cuts only one site within T-DNA. Then, digested DNA was loaded onto the $0.8 \%(\mathrm{w} / \mathrm{v})$ agarose gel and blotted to a positively charged nylon membrane according to the instruction (HAYBOND N+, Amersham, Little Chalfont, UK). The probe corresponding to a PCR product of the TPS2 target gene was produced and detection was done by DIG detection kit (Boehringer, Mannheim, Germany). Air-dried leaves and inflorescence of transformed and non-transformed herbs were grounded and extracted. Afterward, water liquid chromatography was conducted to determine thymol content [40].

\section{Statistical analysis}

The treatments were conducted as factorial experiments based on a completely randomized design (CRD) with 3 replications. Mean comparisons were performed through Duncan's multiple range test $(P<0.05)$ using SAS software (version 9.3). Excel was used for plotting.

\section{Results}

\section{Callus induction and regeneration}

Callus induction and regeneration of T. ammi were acquired in all tested treatments (zygotic embryos and different concentrations of plant growth regulators) on MS and B5 media. The B5 medium indicated abundant 
callus induction from days 8 to 10 . The B5 media supplemented with $0.5 \mathrm{mg} / \mathrm{l} \mathrm{BA}$ and $1 \mathrm{mg} / \mathrm{l} \mathrm{NAA}$ were also observed to be the foremost treatment for callus induction. The MS media supplemented with $1 \mathrm{mg} / \mathrm{l}$ 2,4-D, and $0.2 \mathrm{mg} / \mathrm{l} \mathrm{KIN}$ also demonstrated high callus induction (Table 1). Moreover, plant regeneration on B5 and MS media demonstrated a good rate with all treatments so that the range of regeneration changed from 41.1 to 92.6\% (Table 1). Fresh and dry weights of calli also varied from 0.27 to $0.53 \mathrm{mg}$ and from 0.018 to $0.034 \mathrm{mg}$, respectively. Furthermore, the height of the regenerated shoots was varied from 5.53 to $10.23 \mathrm{~cm}$ (Table 1). A comparison made between the treatments demonstrated that the highest percentage of regeneration for this ecotype (Shaheideh Yazd) was obtained in B5 medium with $0.5 \mathrm{mg} / \mathrm{l} \mathrm{BA}$ together with $1 \mathrm{mg} / \mathrm{l} \mathrm{NAA}$. We only used this medium in plant transformation since this medium showed the best regeneration in tissue culture. Callus induction, regeneration, and growth of zygotic embryo have been shown in Fig. 1.

\section{Determination of threshold concentrations of kanamycin and GUS expression in transgenic plants}

By studying the effect of kanamycin on the embryo culture, we noticed that calluses appeared in $0,5,10,15$, 20,25 , and $30 \mathrm{mg} / \mathrm{l}$ kanamycin but their initiation and growth were delayed by increasing kanamycin levels. Additionally, for higher concentrations of kanamycin, no callus induction was observed (Fig. 2c). Kanamycin concentrations $(0,5$, and $10 \mathrm{mg} / \mathrm{l})$ showed plant regeneration, and there was no regeneration at high concentrations of kanamycin $(15,20,25,30,50$, and $75 \mathrm{mg} / \mathrm{l})$ (Fig. $2 \mathrm{~d})$. So, $15 \mathrm{mg} / \mathrm{l}$ concentration was applied as a threshold level of kanamycin for choosing the putative transgenic herbs. Findings the inoculation and co-cultivation time of LBA4404 harboring pBI121 with GUS gene also illustrated that $30 \mathrm{~s}$ inoculation along with 1-day cocultivation had the most callus induction (Fig. 2a). Results of inoculation and co-cultivation time for regeneration showed that $30 \mathrm{~s}$ inoculation with 1-day cocultivation had the most regeneration. These conditions were showed to be also appropriate for gene transferring process (Fig. 2b). Further, the existence of the GUS gene was confirmed with the presence of $450 \mathrm{bp}$ fragments in $2 \%$ agarose gel. As it is observed in Fig. 3b, no PCR segment has been amplified in the non-transformed and the control sample (deionized water). The $470 \mathrm{bp}$ segment has been amplified using the nptII specific primers (Fig. $3 \mathrm{~b})$. Also, to demonstrate the nonexistence of bacterial pollution, VIR G-specific primer was utilized. The fragments of $850 \mathrm{bp}$ were obtained as a positive control using VIR G primer, and there was no any fragment for transformed plants on an agarose gel, confirming the nonexistence of Agrobacterium contamination in transformed plants (Fig. 3b). Results of histochemical GUS analysis, on the other hand, verified the existence of the
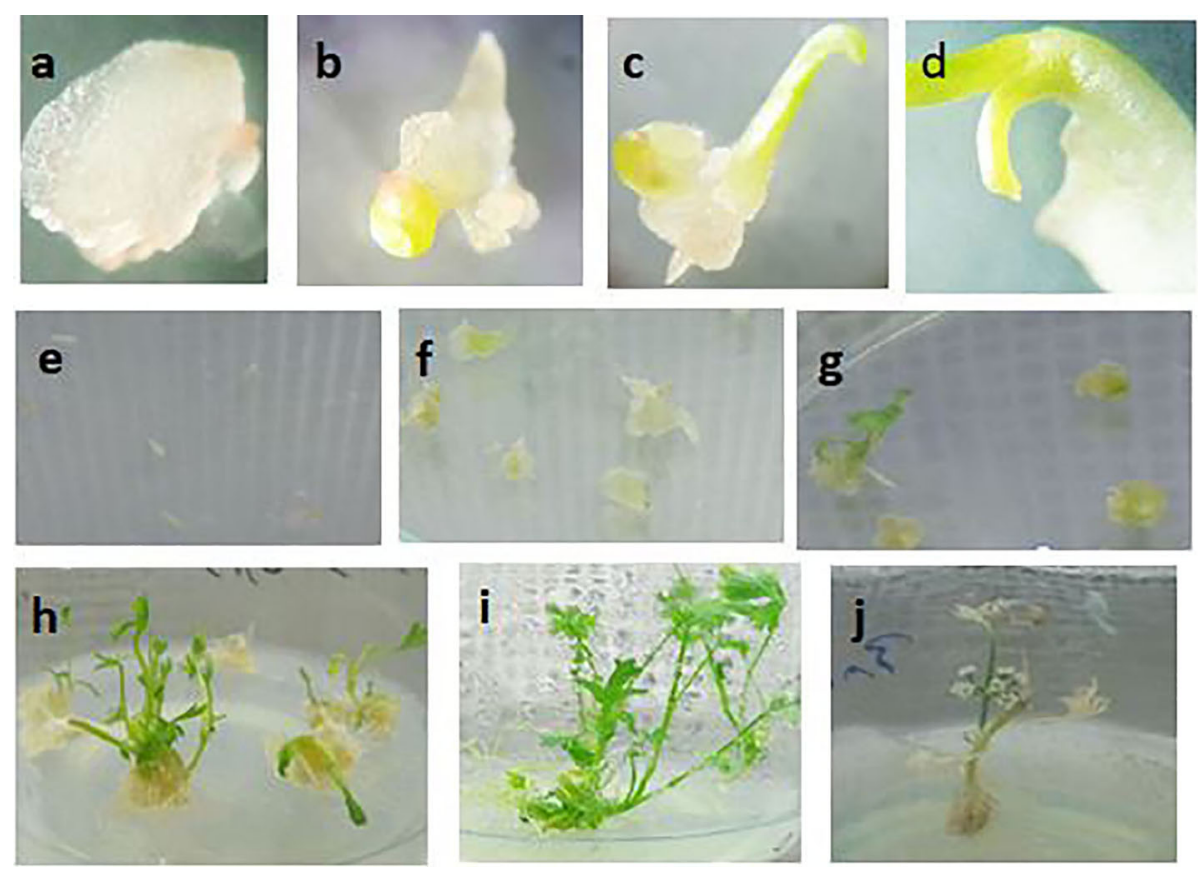

Fig. 1 In vitro regeneration of Trachyspermum ammi using zygotic embryos. a Callus formation. b Callus development. c Monopolar regeneration. d Leaf emergence. e Isolated embryo on B5 media supplemented with $0.5 \mathrm{mg} / \mathrm{l} \mathrm{BA}$ and $1 \mathrm{mg} / \mathrm{INAA}$. $\mathbf{f}$ Callus induction from mature embryos. $\mathbf{g}$ Shoot regeneration from an embryo-derived callus. $\mathbf{h}$ Elongation of shoot and root. $\mathbf{i}$ Regenerated plantlet from the zygotic embryo. and $\mathbf{j}$ The appearance of the inflorescence 

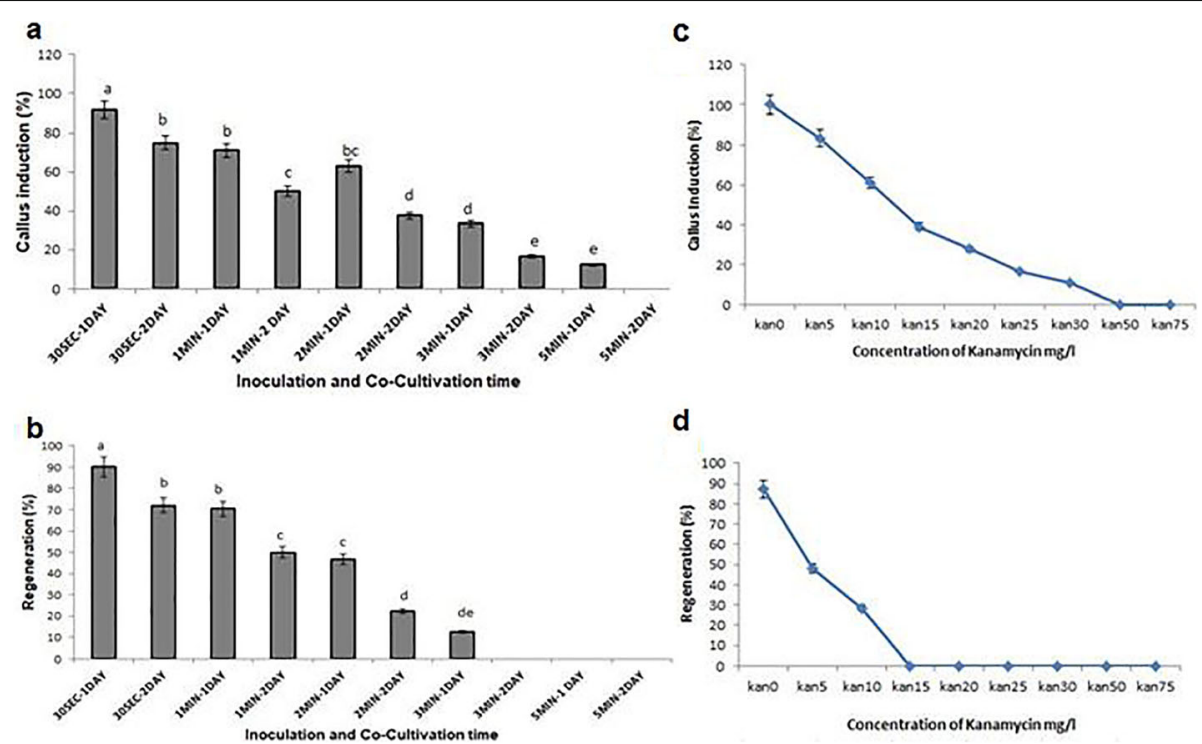

Fig. 2 a, b Calluses' induction and regeneration of Trachyspermum ammi by Agrobacterium LBA4404 harboring GUS gene based on inoculation time (30s, 1, 2, 3, and $5 \mathrm{~min}$ ) and co-cultivation (1 and 2 days). To measure each treatment, all experiments were repeated up to three times. Different letters (a-e) specify a significant difference between treatments based on Duncan's test at $P \leq 0.05$. $\mathbf{c}$, $\mathbf{d}$ The mean comparison of the percentage of callus induction and regeneration of T. ammi at different concentrations of kanamycin

blue color in transformed and no color in the nontransformed herbs (Fig. 3a). To approve the final expression of GUS in a transgenic plant, we carried out RTPCR by GUS-specific primer. No bond existed in the control herb (Fig. 3b). Based on these results, the integrating the T-DNA harboring the GUS gene into the plant genome was verified. Hence, on the basis of the confirmation of gene existence in the plants and regenerating plants in the kanamycin culture medium, we can conclude that the regenerated plant is transgenic.
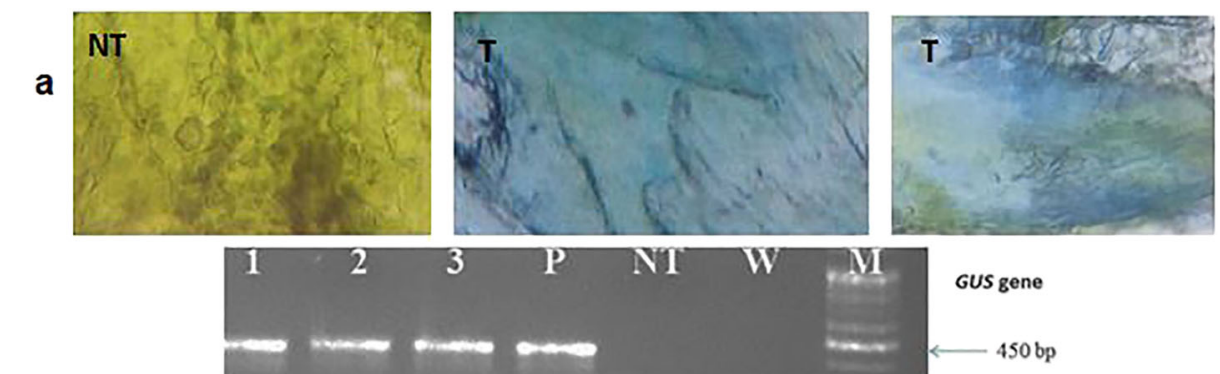

b
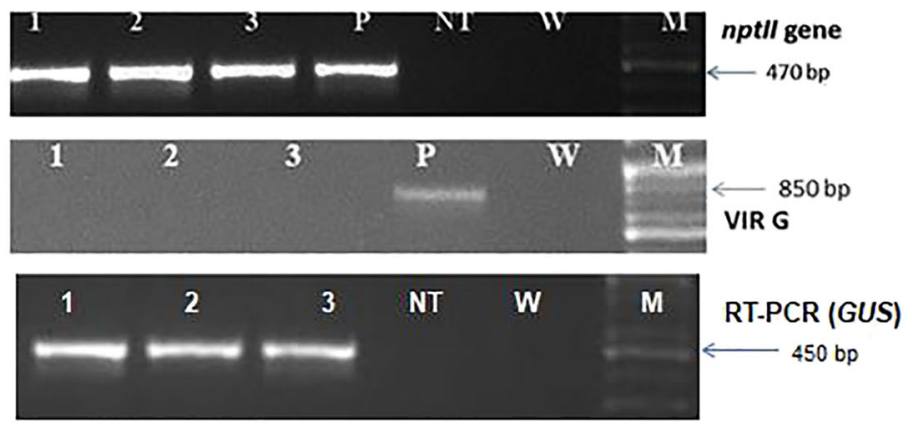

Fig. 3 a Histochemical GUS assay using Trachyspermum ammi leaves, T: Putative transformed plant, NT: non-transformed plant (control); b Results related to PCR analysis of GUS, nptII, VIR G, and RT-PCR analysis. 1-3 putative transgenic plant, P: positive control (plasmid), NT: non-transformed herb, W: negative control, M: 100 bp DNA ladder 
a
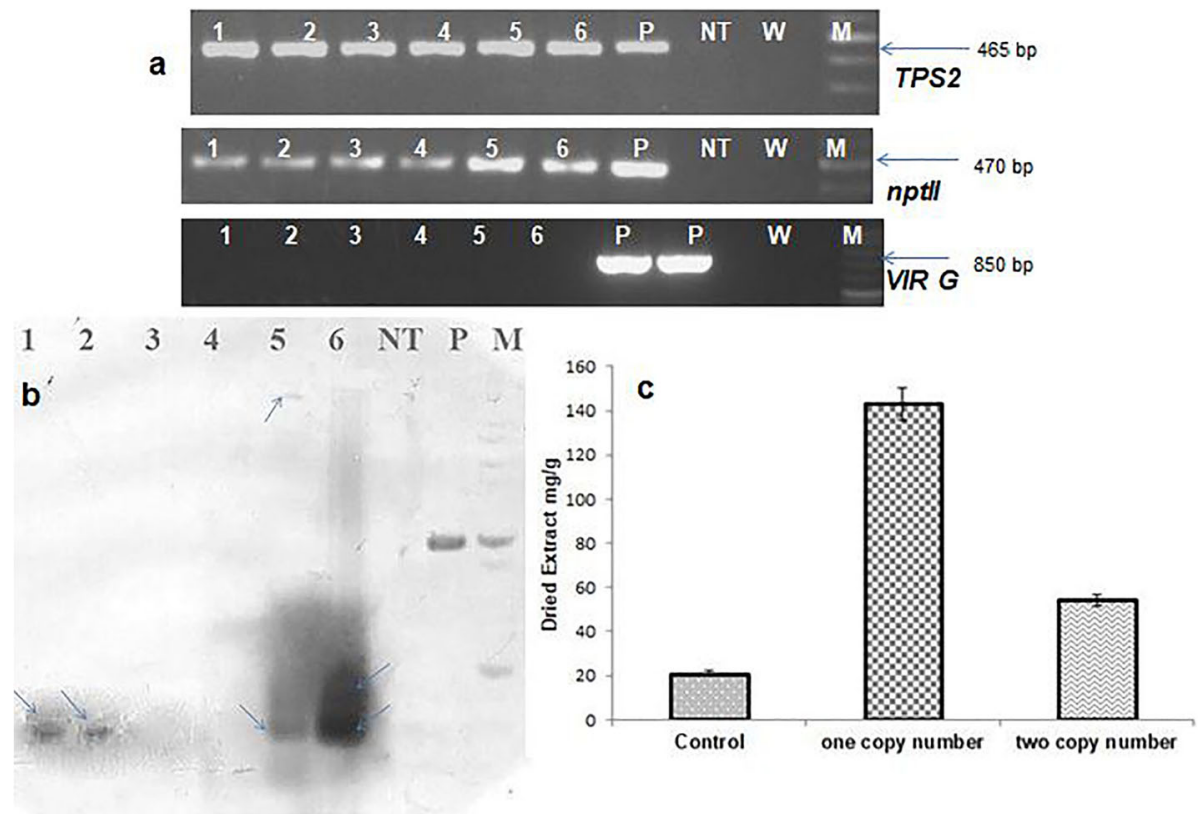

Fig. 4 a Detection of putative transgenic Trachyspermum ammi by PCR 1-3: putative transgenic plant using LBA4404, 4-6: putative transgenic plants using EHA101; NT: non-transgenic plant; P: positive control (plasmid) W: negative control (deionized water); M:100 bp DNA ladder. b DNAblot analysis of transformed and non-transformed T. ammi. 1, 2, 5, and 6 transgenic plants; NT: non-transformed plant; P: positive control; M: marker (digestion of total genomic DNA was performed using EcoRl). c Results of Thymol content (mg/g plant dried extract) of transformed and non-transformed T. ammi using HPLC methods. One copy or two copy numbers were determined using DNA-blot analysis

\section{TPS2 expression in transgenic plants}

Meanwhile, a PCR amplification of 465 bp TPS2 gene was proved in putative transgenic herbs (Fig. 4a). Following, the PCR was accomplished by specific primers of $n p t I I$ and was verified with the presentation of $470 \mathrm{bp}$ fragment on an agarose gel (Fig. 4a). PCR was also accomplished with VIR $G$ primer to confirm lack of bacterial contamination. As a positive control, Agrobacterium indicated a fragment of 850 bp (Fig. 4a). Based on the outcomes of PCR, transformed herbs
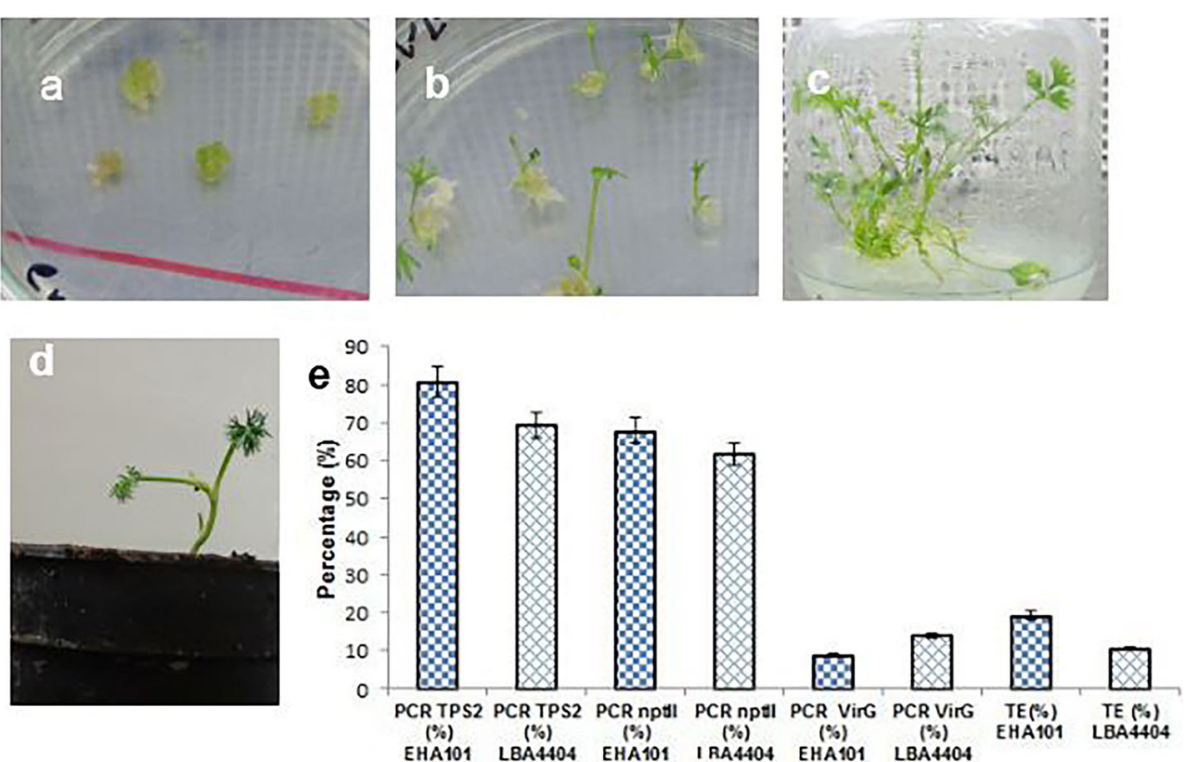

Fig. 5 Agrobacterium-mediated transformation of Trachyspermum ammi. a Callus induction in selective media containing kanamycin and cefotaxime from zygotic embryos. b Development of shoot and root. c Putative transgenic plant. $\mathbf{d}$ Acclimatized transgenic plant in the pot. e Percentage of PCR results of transformed T. ammi, and TE: transformation efficiency 
showed the transformation efficiency of $19.29 \%$ (EHA101) and 10.52\% (LBA4404) (Fig. 5e). Moreover, six putative transgenic plants approved by repeated PCR analysis were analyzed via DNA hybridization to indicate the additional combination of the TPS2 gene into the genome of transgenic herbs. Different models were observed for hybridizing in 4 out of 6 putative transgenic herbs. The results revealed one insert (two lanes 1 and 2 ) and more than one fragment (two lanes 5 and 6). No band was found in the non-transformed herb (lane NT) (Fig. 4b). Outcomes of HPLC of Trachyspermum ammi also indicated the highest thymol level in the transformed herbs. The thymol level was $143.90 \mathrm{mg} / \mathrm{g}$, in the dried extract of transformed herbs (one copy number), $54.40 \mathrm{mg} / \mathrm{g}$ in the dried extract of transformed herbs (two copy number) and it was 21.09 $\mathrm{mg} / \mathrm{g}$ in the dried extract of non-transformed herbs (Fig. 4c). These results showed 7-fold increment in thymol content (one copy number) and 2.5-fold increment (two copy number) than the non-transgenic plant. Several steps of regenerating the putative transgenic herbs are shown in Fig. $5 \mathrm{a}-\mathrm{d}$.

\section{Discussion}

Numerous plants have potential medicinal uses and mainly contain valuable secondary metabolites representing anti-cancer, anti-inflammatory, antioxidant, and antimicrobial properties. The growing demand for these plant secondary metabolites suggests the use of biotechnology tools to produce transgenic plants in vitro. These methods have yielded valuable results and revealing that the production of transgenic plants is efficient and costeffective to produce valuable secondary metabolite resources for medicine and industry [41].

Tissue culture methods are greatly applied to conserve and reproduce the medicinal plants that are laborious and time-consuming to propagate by conventional methods. Zygotic embryos are appropriate explants to regenerate plants because these explants, with convenient culture media, can produce many plants in the least time and with great proficiency. Different combinations of auxins and cytokinins were applied to regenerate $T$. ammi. Our results illustrated that the best treatment for callus induction and regeneration of plant was the B5 medium supplemented with $0.5 \mathrm{mg} / \mathrm{l} \mathrm{BA}$ and $1 \mathrm{mg} / \mathrm{l}$ NAA. B5 medium with NAA and BA has been used to regenerate some plants from zygotic embryo explants [42, 43]. Results of our study illustrated that BA is necessary for regeneration by zygotic embryo. This has been supported by some previous studies $[44,45]$. Moreover, the findings illustrated that zygotic embryo transformation was a suitable procedure for high regeneration and quick growth of T. ammi.

One of the most important ways to produce valuable plant secondary metabolites is to manipulate plant metabolic pathways by overexpressing or silencing selected elements in their biosynthesis pathway [41, 46]. Metabolic pathway manipulation is performed to increase the content of secondary metabolites (terpenoids) in the cultivation of many laboratory plants [47-49]. The results of this study showed that the T. ammi is transformed with both strains of Agrobacterium (transformation efficacy: EHA101 (19.29\%), LBA4404 (10.52\%). Hoseini et al. studied the transformation of Arabidopsis thaliana by the as part insulin gene and two Agrobacterium tumefaciens strains (EHA101 and GV 3101). They found that the EHA101 strain of Agrobacterium was more efficient than the GV3101 strain in gene transformation [50]. Pandey et al. [51] used two strains LBA4404 and EHA101 for the transformation of Withania somnifera (L.) Dunal. They demonstrated that LBA4404 had more gusA expression compared to EHA101. In our study, DNA hybridization was utilized for further verification of the combination of the TPS2 gene into the plant genome. We found that the different dimensions of hybridization signals are caused by the stable T-DNA combination with the genome rather than endophytic Agrobacterium pollution. Moreover, according to HPLC analysis, a transgene copy can have a high potential for increasing gene expression in the transgenic T. ammi. Ma et al. found one to three copies of DNA hybridization fragments in transformed Veratrum dahuricum [52]. Dai et al. [53] reported that transgenic plants with more copy numbers of transgene showed lower level of GUS gene activity. It could be due to gene silencing mechanism. However, Alvarez [54] reported that copy number has no effect on foreign gene expression.

The production of high-capacity transgenic plants to produce valuable plant compounds creates a new field for discovering natural molecules, derived from both plants or plant-microbial interactions, for medical and other valuable purposes [55]. Vamenani et al. [56] showed that the transformation of Ttrachyspermm ammi by Agrobacterium rhizogenes strains (A4, LBA 9402, ATCC 15834) and seedling stem can increase thymol content $(11.30 \mathrm{mg} /$ g DM). This study demonstrated 5.3-fold enhancement of biomass and thymol agglomeration. In another study, to enhance drought and salinity tolerance in $T$. ammi, betaine aldehyde dehydrogenase gene and hypocotyl explants were used. The results showed enhancement thymol level in both wild type and transformed plants of ajowan (39.2 and $55.07 \%$ ) by the drought stress [57]. In another study conducted by Sharma et al. [58], it was found that overexpression of Tryptophan decarboxylase and strictosidine synthase in Catharanthus roseus increased vindoline, catharanthine, and vinblastine content.

\section{Conclusions}

In the current research, a fast protocol was introduced for the transformation of Trachyspermum ammi, using 
zygotic embryo explants within 25-35 days. The introduced protocol displayed the integration of TPS2 gene with transgenic plants and the transformation efficiency 19.29\%. Finally, HPLC analysis confirmed the increase of thymol in the aerial part of T. ammi due to expression of TPS 2 gene (one copy number). Overall, this study could be a practical protocol to enhance significant constituents in this plant; therefore, it can be beneficial for biotechnological research studies and pharmaceutical uses.

\section{Abbreviations}

MS: Murashige and Skoog; B5: Gamborg's B5; BA: 6-Benzyladenine; NAA: 1Naphthaleneacetic acid; 2,4-D: 2,4-Dichlorophenoxyacetic acid; KIN: Kinetin; GUS: $\beta$-Glucuronidase

\section{Acknowledgements}

The authors are thankful to the Biotechnology Development Council of the Islamic Republic of Iran for the financial support provided for this study.

\section{Authors' contributions}

MN performed the experiments and analyzed the results and wrote the paper. MT designed the experiment and edited the finalized the paper. The authors have read and approved the manuscript and ensure that this is the case.

\section{Funding}

This research was supported financially by Code No. 950805 of the Biotechnology Development Council of the Islamic Republic of Iran. The organization provided part of the fund for this research.

\section{Availability of data and materials}

Not applicable

\section{Declarations}

Ethics approval and consent to participate

Not applicable.

\section{Consent for publication}

Not applicable

\section{Competing interests}

There are no competing interests.

\section{Author details}

'Department of Agronomy and Plant breeding - College of Aburaihan, University of Tehran, Tehran, Iran. '2Department of Plant Biotechnology College of Life Science and Biotechnology, Shahid Beheshti University, Daneshjou Boulevard, Tehran 19839-63113, Iran.

Received: 3 November 2020 Accepted: 27 April 2021

Published online: 11 May 2021

\section{References}

1. Jawahar M, Karthikeyan AVP, Vijai D, Maharajan M, Ravipaul S, Jeyseelan M (2008) In vitro plant regeneration from different explants of cardiospermum helicacabum L. Int J Biol Chem Sci 2(1):14-20

2. Tripathi L, Tripathi JN (2003) Role of biotechnology in medicinal plants. Trop J Pharm Res 2:243-253

3. Koca A, Aasim M (2015) Establishment of efficient micro propagation system in Bishops weed ( Trachyspermum ammi) using seed as explant. J Anim Plant Sci 25:478-484

4. Purohit S, Kothari SL (2007) Direct somatic embryogenesis from cotyledon and cotyledonary node explants in bishops weed Trachyspermum Ammi (L.) spraque. In Vitro Cell Dev Biol Plant 43(2):154-158. https://doi.org/10.1007/ s1 1627-007-9039-4
5. Salehi M, Hosseini B, Jabbarzade Z (2014) High-frequency in vitro plantlet regeneration from apical bud as a novel explant of Carum copticum L. Asian Pac J Trop Biomed 4:424-428

6. Teymourian H, Ebrahimi MA, Tohidfar M, Farsaloon N, Zarinpanjeh N (2017) In vitro plantlet regeneration from callus culture of Trachyspermum copticum. Plant Tissue Cult \& Biotech 27(1):13-20. https://doi.org/10.3329/ ptcb.v27i1.35007

7. Nomani M, Sadat Noori SA, Tohidfar M, Ramshini H (2021) Regeneration of Trachyspermum ammi L. Sprague ecotypes via indirect somatic embryogenesis using hypocotyl and epicotyl explants. Indian J Exp Biol 58: 263-269

8. Rao MS, Purohit SD (2006) In vitro shoot bud differentiation and plantlet regeneration in (Celastrus Paniculatus). Biologica Plantrum 50(4):501-506. https://doi.org/10.1007/s10535-006-0079-0

9. Siddique I, Javed SB, Al-Othman MR, Anis M (2013) Stimulation of in vitro organogenesis from epicotyl explants and successive micro propagation round in Cassia angustifolia Vahl: an important source of sennosides. Agroforestry Systems 87(3):583-590. https://doi.org/10.1007/s10457-012-9578-5

10. Udayakumar R, Choi CW, Kim KT, Kim SC, Kasthurirengan S, Mariashibu TS, Sahaya Rayan JJ, Ganapathi A (2013) In vitro plant regeneration from epicotyl explants of Withania Somnifera (L.) Dunal. J Med Plants Res 7:43-52

11. Kumar J, Gupta PK (2008) Molecular approaches for improvement of medicinal and aromatic plants. Plant Biotechnol Rep 2(2):93-112. https://doi. org/10.1007/s11816-008-0059-2

12. Urbanova M, Kosuth J, Cellarova E (2006) Genetic and biochemical analysis of Hypericum perforatum L. Plants regenerated after cryopreservation. Plant Cell Rep 25(2):140-147. https://doi.org/10.1007/s00299-005-0050-0

13. Lu X, Tang K, Li P (2016) Plant metabolic engineering strategies for the production of pharmaceutical terpenoids. Front Plant Sci 7:1647

14. Cheng AX, Lou YG, Mao YB, Lu S, Wang LJ, Chen XY (2007) Plant terpenoids: biosynthesis and ecological functions. J Integrative Plant Biol 49(2):179-186. https://doi.org/10.1111/j.1744-7909.2007.00395.x

15. Kappers IF, Aharoni A, Van Herpen TWJM, Luckerhoff LLP, Dicke M, Bouwmeester HJ (2005) Genetic engineering of terpenoid metabolism attracts bodyguards to Arabidopsis. Science 309(5743):2070-2072. https:// doi.org/10.1126/science.1116232

16. Chen F, Tholl D, Bohlmann G, Pichersky E (2011) The family of terpene synthases in plants: a mid-size family of genes for specialized metabolism that is highly diversified throughout the kingdom. Plant J 66(1):212-229. https://doi.org/10.1111/j.1365-313X.2011.04520.x

17. Lima AS, Schimmel J, Lukas B, Novak J, Barroso JG, Figueiredo AC, Pedro PG, Degenhardt J, Trindade H (2013) Genomic characterization, molecular cloning and expression analysis of two terpene synthases from Thymus caespititius (Lamiaceae). Planta 238(1):191-204. https://doi.org/10.1007/s00425-013-1884-2

18. Poulose AJ, Croteau R (1978) Gamma-Terpinene synthetase: a key enzyme in the biosynthesis of aromatic monoterpenes. Arch Biochem Biophys 191(1):400-411. https://doi.org/10.1016/0003-9861(78)90104-2

19. Frick S, Kramell R, Kutchan TM (2007) Metabolic engineering with a morphine biosynthesis P450 in opium poppy surpasses breeding. Metab Eng 9(2):169-176. https://doi.org/10.1016/j.ymben.2006.10.004

20. Ziegler J, Voigtiander S, Schmidt J, Kramell R, Miersch O, Ammer C, Gesell A Kutchan TM (2006) Comparative transcript and alkaloid profiling in papaver species identifies a short chain dehydrogenase/reductase involved in morphine biosynthesis. Plant J 48(2):177-192. https://doi.org/10.1111/j.13 65-313X.2006.02860x

21. Ishikawa T, Sega Y, Kitajima J (2001) Water-soluble constituents of Ajowan. Chem Pharm Bull 49(7):840-844. https://doi.org/10.1248/cpb.49.840

22. Jeet K, Devi N, Narender T, Sunil T, Lalit S, Raneev T (2012) Trachyspermum ammi: Acomperhensive review. Int Res J Pharm 3(5):133-138

23. Pandey S, Patel MK, Mishra A, Jha B (2016) In planta transformed Cumin (Cuminum cyminum L.) Plants, overexpressing the SbNHX1 gene showed enhanced salt endurance. PLoS One 11(7):1-18

24. Deguchi M, Bogush D, Weeden H, Spuhler Z, Potlakayala S, Kondo T, Zhang ZJ, Rudrabhatla S (2020) Establishment and optimization of a hemp (Cannabis sativa L.) agroinfiltration system for gene expression and silencing studies. Scientific Reports 10:3504

25. Puc AY, Berzunza EA, Chan-Bacab MJ, Pena Rodriguez LM, Hernandez GG (2012) Agrobacterium- mediated transient transformation of Pentalinon andrieuxii Mull. Arg. Adv Biosci Biotechnol 3:256-258

26. Yadav SH, Sharma P, Strivastava A, Desai P, Shrivastava N (2014) Strain specific Agrobacterium-mediated genetic transformation of Bacopa 
monnieri. J Genet Eng Biotechnol 12(2):89-94. https://doi.org/10.1016/j. jgeb.2014.11.003

27. Koohzadi F, Omidi M, Solouki M, Mahdinejhad N (2016) Overexpression of TYDC2 in medicinal plant opium poppy to increase its medicinal alkaloids contents. Modern Genet J 7(4):343-352 (In Persian)

28. Sharafi A, Hashemi Sohi H, Mousavi A, Azadi P. Hosseini Khalifani B, Razavi K (2013) Metabolic engineering of morphinan alkaloids by overexpression of codeinone reductase in transgenic hairy roots of Papaver bracteatum, the Iranian poppy. Biotechnol Lett 35(3):445-453

29. Yang N, Zhou W, Su J, Wang X, Li L, Wang L, Cao X, Wang Z (2017) Overexpression of SmMYC2 Increases the production of phenolic acids in Salvia miltiorrhiza. Front Plant Sci 8(1804). https://doi.org/10.3389/ fpls.2017.01804

30. Jiang W, Fu X, Pan Q, Tang Y, Shen Q, Lv Z et al (2016) Overexpression of AaWRKYY leads to an enhanced content of artemisinin in Artemisia annua. BioMed Res Int 4:1-9

31. Shen Q, Chen YF, Wang T, Wu SY, Lu X, Zhang L, el. (2012) Overexpression of the cytochrome P450 monooxygenase (cyp7lav1) and cytochrome P450 reductase (cpr) genes increased artemisinin content in Artemisia annua (Asteraceae). Genet Mol Res 11(3):3298-3309. https://doi.org/10.4238/2012. September.12.13

32. da Silva D, Imakawa AM, de Souza CS, Barbosa Sampaio PDT (2018) In vitro culture of zygotic embryos and seeds of Caesalpinia ferrea Martius. Hoehnea 45(4):663-668. https://doi.org/10.1590/2236-8906-65/2018

33. Oh MJ, Na HR, Choi HK, Liu JR, Kim SW (2010) High frequency plant regeneration system of Nymphoides coreana via somatic embryogenesis from zygotic embryo-derived embryogenic cell suspension cultures. Plant Biotechnol Rep 4(2):125-128. https://doi.org/10.1007/s11816-010-0126-3

34. Prudente DOD, Paiva R, Carpentier S, Swennen R, Crlota Nery F, Cautinho Silva L, Panis B (2017) Characterization of the formation of somatic embryos from mature zygotic embryos of Passiflora ligularis Juss. Plant Cell Tissue Organ cult 131:95-107

35. Raomai SH, Kumaria S, Tandon P (2014) Plant regeneration through direct somatic embryogenesis from immature zygotic embryos of the medicinal plant, Paris polyphylla Sm. Plant Cell Tissue Organ cult 118(3):445-455. https://doi.org/10.1007/s11240-014-0496-2

36. Murashinge T, Skoog F (1962) A revised medium for rapid growth of and bioassays with tobacco tissue cultures. Physiol Plant 15(3):473-497. https:// doi.org/10.1111/j.1399-3054.1962.tb08052.x

37. Gamborg OL, Miller RA, Ojima O (1968) Nutrient requirements of suspension cultures of soybean root cell. Exp Cell Ress 50(1):151-158. https://doi.org/10.1016/0014-4827(68)90403-5

38. Nomani M, Sadat Noori S, Tohidfar M, Ramshini H (2019) Overexpression of TPS2 gene to increase thymol content using Agrobacterium tumefaciensmediated transformation in Trachyspermum ammi (Qom ecotype). Ind Crop Prod 130:63-70. https://doi.org/10.1016/j.indcrop.2018.12.076

39. Jefferson RA, Kavanagh TA, Bevan MV (1987) GUS fusion: Bglucuronidase as a sensitive and versatile gene fusion marker in higher plants. Eur Mol Biol Organization J 6(13):3901-3907. https://doi.org/10.1 002/j.1460-2075.1987.tb02730.x

40. Gedikoğlu A, Sökmen M, Civit A (2019) Evaluation of Thymus vulgaris and Thymbra spicata essential oils and plant extracts for chemical composition antioxidant, and antimicrobial properties. Food Sci Nutr 7(5):1704-1714. https://doi.org/10.1002/fsn3.1007

41. Kowalczyk T, Wieczfinska J, Skała E, Sliwinski T, Sitarek P (2020) Transgenesis as a tool for the efficient production of selected secondary metabolites from plant in vitro cultures. Plants 9(2):132. https:/doi.org/10.3390/plants9020132

42. Pandey S, Mishra A, Kumar Patel M, Jha B (2013) An efficient method for agrobacterium-mediated genetic transformation and plant regeneration in cumin (Cuminum cyminum L.). Appl Biochem Biotechnol 171(1):1-9. https:// doi.org/10.1007/s12010-013-0349-1

43. Rosa YB, Dornelas MC (2011) In vitro plant regeneration and de novo differentiation of secretory trichomes in Passiflora foetida L. (Passifloraceae). Plant Cell Tissue Organ Cult 108:91-99

44. Barky F (2008) Zygotic embryo rescue in bananas. Fruits 63:111-115

45. Uma S, Lakshmi S, Saraswathi MS, Akbar A, Mustaffa M (2011) Embryo rescue and plant regeneration in bananana (Musa spp.). Plant Cell Tissue Organ Cult 105(1):105-111. https://doi.org/10.1007/s11240-010-9847-9

46. Zhou M, Memelink J (2016) Jasmonate-responsive transcription factors regulating plant secondary metabolism. Biotecnol Adv 34(4):441-449. https://doi.org/10.1016/j.biotechadv.2016.02.004
47. Mendoza-Poudereux I, Muñoz-Bertomeu J, Navarro A, Arrillaga I, Segura J (2014) Enhanced levels of S-linalool by metabolic engineering of the terpenoid pathway in spike lavender leaves. Metab. Eng 23:136-144. https:// doi.org/10.1016/j.ymben.2014.03.003

48. Wang Q, Reddy VA, Panicker D, Mao HZ, Kumar N, Rajan C, Venkatesh PN, Chua NH, Sarojam R (2016) Metabolic engineering of terpene biosynthesis in plants using a trichome-specific transcription factor MsYABBY5 from spearmint (Mentha spicata). Plant Biotechnol J 14(7):1619-1632. https://doi. org/10.1111/pbi.12525

49. Kang YM, Park DJ, Lee DG, Song HJ, Kang SM, Min JY, Moon BC, Lee CK, Jeon KS, Shivappakarigar C et al (2015) Over expression of IPP isomerase and limonene synthase enzymes in Mentha spicata and their influence on the terpenoid metabolism. Rom Biotechnol Lett 20:10358-10368

50. Hoseini B, Sharifi Sirchi G (2014) Transformation and expression of recombinant insulin monomer in Arabidopsis plant. Genet Eng Biosafety J 3(2):96-105 (In Persian)

51. Pandey V, Misra P, Chaturvedi P, Mishra MK, Trivedi PK, Tuli R (2009) Agrobacterium tumefaciens-mediated transformation of Withania somnifera (L.) Dunal: an important medicinal plant. Plant Cell Rep 29:133-141

52. Ma R, Yu Z, Cai Q, Li H, Dong Y, Oksman-Caldentey KM, Rischer H (2020) Agrobacterium-mediated genetic transformation of the medicinal plant Veratrum dahuricum. Plants 9(2):191. https://doi.org/10.3390/plants9020191

53. Dai S, Zheng P, Marmay P, Zhang S, Tian W, Chen S, Beachy RN, Fauquet C (2001) Comparative analysis of transgenic rice plants obtained by Agrobacterium-mediated transformation and particle bombardment. Molecular Breeding 7(1):25-33. https://doi.org/10.1023/A:1009687511633

54. Alvarez JM, Canessa P, Mancilla RA, Polanco R, Santibáñez PA, Vicuña R (2009) Expression of genes encoding laccase and manganese-dependent peroxidase in the fungus Ceriporiopsis subvermispora is mediated by an ACE1-like copper-fist transcription factor. Fungal Genet Biol 46(1):104-111. https://doi.org/10.1016/j.fgb.2008.10.002

55. Cardoso JC, Oliveira MEBS, Cardoso FCI (2019) Advances and challenges on the in vitro production of secondary metabolites from medicinal plants. Horticultura Brasileira 37(2):124-132. https:/doi.org/10.1590/s0102-053620190201

56. Vamenani R, Pakdin-Parizi A, Mortazavi M, Gholami Z (2019) Establishment of hairy root cultures by Agrobacterium rhizogenes mediated transformation of Trachyspermum ammi L. for the efficient production of thymol. Biotechnol Appl Biochem 67(3):389-395

57. Niazian M, Sadat-Noori S, Tohidfar M, Galuszka P, Mortazavian M (2019) Agrobacterium-mediated genetic transformation of ajowan (Trachyspermum ammi (L.) Sprague): an important industrial medicinal plant. Ind Crop Prod 132:29-40. https://doi.org/10.1016/j.indcrop.2019.02.005

58. Sharma A, Verma P, Mathur A, Mathur AK (2018) Genetic engineering approach using early Vinca alkaloid biosynthesis genes led to increased tryptamine and terpenoid indole alkaloids biosynthesis in differentiating cultures of Catharanthus roseus. Protoplasma 225:425-435

\section{Publisher's Note}

Springer Nature remains neutral with regard to jurisdictional claims in published maps and institutional affiliations.

\section{Submit your manuscript to a SpringerOpen ${ }^{\circ}$ journal and benefit from:}

- Convenient online submission

- Rigorous peer review

- Open access: articles freely available online

- High visibility within the field

- Retaining the copyright to your article

Submit your next manuscript at $\boldsymbol{\nabla}$ springeropen.com 